\title{
Eco 2020: Monetary Policy for the Future Central Bank and Economic Development in West Africa
}

\author{
N’djibio Kokou Charlemagne*, Sylla Doucouré Karima \\ Finance, Entrepreneurship and Accounting Laboratory (LaFEC) of Doctoral School of Economic Sciences and Management, Faculty of \\ Economic Sciences and Management (FASEG), University of Abomey Calavi (UAC), Cotonou, Benin
}

Email address:

ndjibioc@gmail.com (N. K. Charlemagne)

${ }^{*}$ Corresponding author

\section{To cite this article:}

N'djibio Kokou Charlemagne, Sylla Doucouré Karima. Eco 2020: Monetary Policy for the Future Central Bank and Economic Development in West Africa. International Journal of Business and Economics Research. Vol. 10, No. 1, 2021, pp. 50-57.

doi: $10.11648 /$ j.ijber.20211001.17

Received: April 8, 2020; Accepted: April 28, 2020; Published: February 26, 2021

\begin{abstract}
In a context where international political and diplomatic weight also weighs in the game of international monetary cooperation, regional monetary policy can offer to West African countries an opportunity to strengthen their individual and collective position in terms of development, within international cooperation. This vision, based not on the contribution to the resolution of internal monetary problems, but envisaged as an instrument to stem monetary shocks coming from the outside, has not been sufficiently recognized and analyzed, both in the theoretical literature and in considerations of policy makers. Better consideration of this dimension could help steer the debate on monetary integration in the right direction: that of rapid progress towards the single currency. The general objective of this paper is to propose to the political powers, a common monetary policy, able to inject the new dynamism into the economic development of ECOWAS (Economic Community of West African States) countries. This general objective is divided into two specific objectives: analyze the theoretical, economic and political challenges of ECOWAS monetary policy; and to propose a monetary policy adapted to the economic contexts of the ECOWAS countries, and able to inject the new dynamism into the economic development. To achieve these objectives, we carried out a documentary review of the monetary policies currently underway in the countries of West Africa. Next, we relied on the Autoregressive Vector Model with Panel Interactions (IPVAR), following the methodology proposed by Towbin, Pascal \& Weber, Sebastian. An effective monetary policy of the future ECOWAS central bank can boost the development of West African countries.
\end{abstract}

Keywords: Monetary Policy, Economic Development, Central Bank, ECOWAS

\section{Introduction}

The problem of economic integration in general and monetary integration in particular is not new. It goes back to monetary arrangements in Europe at the end of the Second World War and to the debate on exchange rate policy in Canada [1-3]. However, it is Mundell, R. A. who is responsible for the authorship of the debate on monetary unions, following a pioneering study conducted in the context of the fragile international monetary system, which raised the question of the choice of a optimal change [4]. While it is generally accepted that the single currency cancels out the exchange risk and the costs of hedging against this exchange risk, the fact remains that it acts as a bilateral trade subsidy for the countries which have adopted it. It could therefore be favorable to market integration [5]. However, if empirical work has justified the positive link between currency sharing and trade intensification, there is still doubt as to whether such a link exists for a currency union in the making. A generally used approach is that of cost / benefit analysis in the sense of Bean, C. R and Tavlas, G. S. [6, 7]. For these authors, the decision to create (or join) a monetary union depends on the expected positive externalitie.

The rise of regionalism in the world, coupled with the project of adopting a single currency in Africa since the creation of the African Union (AU), require that we look at the potential effects of such a currency in the African Regional Economic Communities (REC). It should be noted that while the issue of integration is not new to Africa, it has, however, experienced a long period of hibernation. The first 
initiative dates back to the day after independence, in 1963, with the Organization for African Unity (OAU), born out of discord between autonomists and federalists.

The process of African integration through the establishment of the African Economic Community is supposed to go through six steps (ie 34 years) as provided for in the Abuja Treaty which entered into force in 1994. This process should theoretically be completed among other things by the creation of an African Central Bank, a single African currency, a Pan-African Economic and Monetary Union. However, aware of the difficulty of creating an African monetary zone at the same time because of strong intra and inter-REC heterogeneities, African leaders opted for a sequential two-step approach. As a first step, each REC will have to establish the conditions for the creation of a single currency within it from a well-established calendar. Secondly, a single African currency will have to be erected from subregional currencies by 2028 . This sequential strategy has led to the creation, consolidation and rationalization of the Regional Economic Communities (REC), with the aim of limiting the multi-ownership of countries with different RECs.

In this dynamic, in 2000, the countries of West Africa expressed their will to accelerate the process of monetary integration started in the early 1980s, which resulted in a project providing for creation in two phases of a single currency in West Africa. This plan provided, in its first step, for the launch in January 2015 of a single currency, the CEE, by the member countries of the West African Monetary Zone (WAMZ). In a second step, the WAMZ was to merge with the West African Monetary Union (WAMU) to create, in 2020, a single currency among all the fifteen member countries of ECOWAS. After three postponements, in 2003, 2005 and 2009, West African officials finally gave up, in July 2014, launching the ECO in January 2015, citing the insufficient level of preparation and economic convergence between the WAMZ member states. On this occasion, they also decided to change strategy by abandoning the intermediate stage of 2015 with the WAMZ single currency, and by reprogramming the creation of a single currency for the whole of ECOWAS for 2020.

Our paper therefore examines the question of the monetary policy to be adopted by the new central bank which will be created to boost economic development in West Africa. Thus, the subject of our work is entitled: "Eco 2020: Monetary Policy for the Future Central Bank and Economic Development in West Africa"

This article is presented according to the plan below:

1. Research context

2. Research issues and objectives

3. Theoretical issues and objectives of monetary policy

4. Heterogeneity and transmission of monetary policy in the ECOWAS zone

5. Synoptic view of monetary policies in ECOWAS countries

6. Summary and proposal of monetary policy favorable to development

\section{Context of the Research}

The Conference of Heads of State and Government of the Economic Community of West African States (ECOWAS) launched the idea of creating a single currency for the first time in 1983 in Conakry (Guinea). Considered for 2020, the adoption of a single currency by ECOWAS would be a decisive step towards greater regional integration. This study analyzes the main challenges of monetary policy to be implemented to boost development in the ECOWAS region. More specifically, we are trying to predict the most development-friendly monetary policy in the ECOWAS region, both for foreign trade and the growth rates of investment and Gross Domestic Product (GDP). According to McKinnon, R. I. (1963), monetary policy is optimal if it achieves full employment, stable price levels and a balanced external balance [8]. The first two criteria refer to internal balance while the third criterion refers to external balance. The founding article of the theory of optimal currency areas identifies four criteria that countries aspiring to adopt a common currency must meet in order for monetary union to benefit them [1]. First, the entire region formed by the countries concerned must have good mobility of the factors of production (that is, capital and labor). Second, the countries concerned must have good nominal flexibility (ie, prices and wages). Third, the countries concerned must subscribe to full sharing of economic risks. And fourth, the countries concerned must share the same economic cycles and have similar rates of shock adjustment. Our aim in this article is not to determine whether the conditions for a monetary union are met within ECOWAS, but to predict which monetary policy would be favorable to the development of ECOWAS countries.

\section{Problem of the Study}

ECOWAS is made up of West African Monetary Union (WAMU), West African Monetary Zone (WAMZ) and Cape Verde. Monetary policy, conducted by the BCEAO (Central Bank of West African States), is common to the eight countries (Benin-Burkina Faso-Ivory Coast-Guinea-BissauMali-Niger-Senegal-Togo) that make up WAMU, while the other countries have their respective central banks.

The primary objective of monetary policy in all ECOWAS countries is to ensure price stability. To this objective are added the sustainability of the balance of payments (external position) in the case of Nigeria and exchange rate stability with regard to The Gambia. Monetary policy is mainly based on market mechanisms and indirect liquidity regulation instruments (minimum reserve system, interest rates and exchange rates). The reserve requirement system regulates the credit distribution capacity of the banking system while interest rates are controlled via open-market and refinancing operations. Nigeria, Guinea and The Gambia are also involved in the foreign exchange market. Unlike other countries, Sierra Leone focuses on the rate of growth of monetary aggregates for the conduct of monetary policy. 
Monetary policy is expected to affect prices and output in the short term through four channels, namely the interest rate, the exchange rate, the price of assets and credit (Mishkin, Frederic S., 1996) [9]. The interest rate channel stipulates that a policy of monetary expansion lowers real interest rates; which lowers the cost of capital and drives up investment. The result is an increase in aggregate demand and production. This mechanism assumes price rigidity in the economy so that a fall in the nominal interest rate leads to a fall in the real interest rate in the short term.

The functioning of the various transmission channels in ECOWAS strongly depends on the structure of the financial system of the countries and on political choices. If the zone opts for a fixed exchange rate regime, the exchange rate channel would not be applicable. Otherwise, the attractiveness of the area will play an important role. The interest rate and asset price channels will depend on the interbank and securities markets in the area. Pooling the interbank markets of all countries would allow for a larger interbank market in terms of volume and a more dynamic debt market. Greater participation of banks in the interbank market is a guarantee for the functioning of the interest rate channel. As for the securities market, if it remains dominated by public securities (as in the WAMU), certain channels will not be able to function properly. Furthermore, the existence and functioning of a secondary market is a sine qua non condition for monetary policy to affect in particular the cost of financing in the region. Under these conditions, what monetary policy of the future central bank could breathe new life into the development of ECOWAS countries?

\section{Research Objectives}

The general objective of this paper is to propose to the political powers, a common monetary policy, capable to infuse a new dynamic into the economic development of the ECOWAS countries.

This general objective is divided into two specific objectives:

a) Analyze the theoretical, economic and political issues of ECOWAS monetary policy;

b) Propose a monetary policy adapted to the economic contexts of the ECOWAS countries, and able to stimulate their economic development.

\section{Theoretical Stakes of Monetary Policy}

In theory, the adoption of a single currency in the ECOWAS region would lead to the disappearance of transaction costs linked to the differences in currencies from one country to another, an expansion of intra-Community trade, an increased mobility of the factors of production and faster growth in real activity. The monetary authority which would be responsible for managing the single currency would see its credibility strengthened by virtue of its regional status, which would ultimately translate into greater macroeconomic stability.
The decision to create a single currency in West Africa is eminently rational, but it also raises very complex questions of political economy, not only between the States of West Africa, but also between them and outside world. Internally, the issue of the single currency should not be limited to the circle of political and economic elites. It is important that the populations are widely informed of the challenges of the project in order to gain their full support and to establish the political choices linked to the introduction of the single currency which will inevitably involve changes and adaptations in the lives of the populations. National and Community parliaments will also have to be regularly informed of the progress of the process so that they also serve as intermediaries with the populations and facilitate the adoption of legal and institutional frameworks linked to the single currency.

It is also necessary that the first political and economic powers of ECOWAS - namely Ivory Coast, Ghana, Guinea, Nigeria, and Senegal - can assume their leadership role and find the synergies necessary to accelerate the implementation in place of the West African Monetary Union (WAMU). Nigeria, the leading economic power in West Africa and the region's main market, must play a catalytic role in the process of establishing monetary union. It must therefore open its market more to regional exports, but above all broaden its prospects and consider neighboring countries as partners and not just customers. Through this monetary union, the West African Monetary and Economic Union (WAEMU) countries, which have acquired in sixty years experience in the common management of a currency, will have to find an opportunity to widen their economic and financial space to all of Africa. West, while preserving their macroeconomic stability.

Towards the rest of the world, the implications for political economy should also be given special attention. It goes without saying that economic considerations, notably involving France, acquire considerable importance. This aspect also refers to the international impact of the West African single currency. While bearing in mind these external issues, it should be recalled that the adoption of a currency is above all a sovereign decision. The creation of the single currency in West Africa should therefore, first of all, depend on the will of the Member States and the support of the people.

According to Arnaud Parienty (2016), monetary policy has traditionally had the function of acting on the rate of inflation and possibly on growth and employment thanks to a set of instruments (regulation of the money supply, of credit, etc.) [10]. Monetary policy saw its theoretical supports renewed in depth at the end of the 1970s and during the 1980s, thanks to a re-evaluation of traditional concepts by the monetarist current. The central aspect of this mutation corresponds to the incorporation of the principle of rational anticipation in predictive models. However, this period seems to be under the sign of a contradiction:

a) on the one hand, in practical terms, monetary policy has been recognized within the policy mix as the preferred 
instrument over budgetary policy.

b) on the other hand, theoretically, the effectiveness of monetary policies based on the exploitation of traditional IS-LM models has been deeply called into question by the monetarist approach. To this apparent contradiction was added an overlay relating to the priority between two objectives of monetary policy: full employment and price stability. The trade-off between growth and inflation was finally made in favor of a priority given to controlling inflation, with the hope that this policy would have a limited impact on growth. In the meantime, faced with the significant volatilities recorded on interest rates, inflation and the uncertainty as to the definition of money supply aggregates, the policy of controlling these money supply aggregates was finally abandoned in favor a policy that uses shortterm key rates, open market policy and reserve policy more directly as instruments. In the early 1990s, the objective conflict between growth and inflation became topical again, partly under pressure from economists of neo-Keynesian inspiration, but above all on the basis of test results. The evolution that is starting leads to a reinforcement of the ambiguity between tools and objectives. Initially the objective and the tool were clearly identified as inflation and money supply.

\section{Monetary Policy Objectives}

We are used to distinguishing four levels within the systems put in place by monetary policies: final objectives, intermediate objectives, indicators and instruments.

a) The final objectives are the ultimate goals pursued by monetary policy (price stability, non-inflationary economic growth or full employment). Monetary policy cannot aim directly at these objectives because the central banks have only very indirect control over these economic magnitudes, which react with rather long and variable shifts to the impulses of monetary policy, and are observed only with a significant delay and a fairly spaced periodicity.

b) Intermediate objectives, such as money aggregates or exchange rates, are therefore put in place. These intermediate targets have no value in themselves, except their correlation with the final goals with which they have a causal relationship. They are better controllable and more quickly observed than the ultimate objectives.

c) The Advances leading indicators are economic variables which provide the central bank with information on the state of the economy (typically: inflationary pressures or expectations or the effective orientation of monetary policy, the degree of its expansive or restrictive).

d) Instruments, sometimes called "operational objectives", are variables that are directly under the control of the central bank. The choice of instruments and the rules defined to manipulate them determine the day-to-day monetary policy. There are two main means of action for the central bank:

1. Action through bank liquidity, whereby the central bank acts on second-tier banks by making them more or less liquid. The central bank plays on liquidity by more or less supplying second-tier banks with money, and by modifying the reserve requirement rate.

2. Interest rate action, where the central bank plays on the three key rates it controls (marginal loan facility rate, deposit facility rate, open market operations rate). Changes in these rates change the behavior of secondtier banks. Most central banks choose the short-term interest rate as their instrument. It is the only rate that a central bank can effectively control precisely. Indeed, very short-term assets are very close to money (liquidity), and the central bank has a monopoly on the issue of money. By controlling short-term interest rates, the central bank has a strong influence on the supply of liquidity. On the other hand, as the maturity increases, the rates incorporate market expectations and thus escape the control of the central bank.

i. THE MEANS OF MONETARY POLICY

Central banks seek through monetary policy instruments to steer rates and their expectations. They thus act on the liquidity of commercial banks.

Two approaches can be conceived:

a) directive approach: based on administrative instruments, regulatory measures (credit framework)

b) suggestive approach: based on market instruments, in this case steering short rates on the interbank market. The central bank is able to direct the liquidity of commercial banks because it issues "high money power" through:

1. Mandatory reserves

2. Bank refinancing (discount rate): the interest rate it applies to commercial banks

3. Open market operations

\section{Heterogeneity and Transmission of Monetary Policy in the ECOWAS Zone}

This section examines how the heterogeneity of ECOWAS economies will affect the efficiency of monetary policy transmission. We simulate a monetary policy shock and test the efficiency of transmission conditional on certain structural characteristics of economies. This analysis is an examination of cyclical heterogeneity.

\subsection{Methodology}

Fundamentally, the heterogeneity of the economies of ECOWAS countries raises the question of the transmission of monetary policy to the real economy. In order to take this heterogeneity into account in the transmission of monetary policy, some studies use heterogeneous VAR models (Misra, Kanishka, and Paolo Surico. 2014) or factor models (Barigozzi, Matteo and Hallin, Mark, 2015) [11, 12]. In 
addition to this work, other researchers use panel approaches with interaction terms estimated by the generalized method of moments (Ehrmann, M., L. Gambacorta, J. Martinez Pagés, P. Sevestre and A. Worms, 2003) [13]. This idea was recently extended to VAR models. The most common models are the VAR model with interactions on panel data or IPVAR) (Towbin, Pascal \& Weber, Sebastian, 2013) and the homogeneous conditional VAR model on panel data or PCHVAR (Georgios Georgiadis, 2014) [14, 15]. In this article, we use the IPVAR approach. This approach has been used to examine the transmission of monetary policy in developing countries (Christian Saborowski; Sebastian Weber, 2013) [16]. In this subsection, we describe the econometric model and the variables used and their sources.

\subsection{Econometric Model}

The main idea of this sub-section is to assess the contribution of heterogeneity in the transmission of monetary policy in ECOWAS. The literature teaches that structural differences within a monetary union can be a source of asymmetry in responses to a common monetary policy. From this perspective, we assess the transmission of monetary policy conditionally to certain peculiarities of the economies studied. To this end, we rely on an Autoregressive Vector Model with Panel Interactions (IPVAR), following the methodology proposed by Towbin and Weber (2013). The recursive form of this model is written as follows:

$$
\begin{aligned}
& \text { Jit } Y \text { i } t=C^{\sim} i+\sum_{\sim} L k=1 \tilde{A^{\sim} k} Y i,-k+C^{\sim} 1 X i t+\sum L \\
& k=1 B^{\sim} k 1 X i t Y i, t-k+\varepsilon i t
\end{aligned}
$$

where $t(t=1, \ldots$,$) is time and i(i=1, \ldots, N)$ the country. Yit is a vector of dimension $q \times 1$ containing the variables of interest, $C^{\sim} i$ is a vector of dimension $\mathrm{q} \times 1$ containing the country fixed effects, $A^{\sim} k$ is a matrix of dimension $q \times q$ of the coefficients of the different delays of order $k(k=1, \ldots$,$) .$ E it $\sim(0, \tilde{\Sigma})$ is the vector of dimension $q \times 1$ of the residuals. The residuals are assumed to be uncorrelated between countries and distributed according to a normal law of variance matrix $\tilde{\Sigma}$ of dimension $q \times q$, invariant in time. Jit is a lower triangular matrix with one (1) on the main diagonal. Xit represents an interaction term which influences the dynamic relationship between endogenous variables $\left(B^{\sim} k 1\right)$ and which eventually affects the level of the variables (via $C^{\sim} 1$ ).

The originality of this approach lies in taking into account an interaction term between endogenous variables and the characteristics of countries (control variables), Xit. This approach allows us to measure the contribution of these characteristics to the transmission of monetary policy from $B \sim k$. By inverting the VAR, it can be shown that the impulse responses vary according to the level of the control variables (characteristics of the countries). We can thus examine more finely whether the transmission of monetary policy is sensitive to the characteristic considered of the countries. In order to appreciate the significance of the responses, a Bootstrap procedure is used to construct the confidence intervals.

\subsection{Monetary Policy Measure Indicator}

The ultimate objective of monetary policy in ECOWAS countries is price stability. Various instruments are used for the conduct of monetary policy; including interest rates and money supply. In the case of this analysis, the monetary policy instrument is derived from the M2 monetary aggregate. Whichever instrument is used, any expansionary policy should be accompanied by an increase in the money supply.

Given the availability of data, we use the monetary aggregates of WAMU, Nigeria, The Gambia, Cape Verde and Ghana for the period 1990-2015.

Over this period, the selected countries represent between 91.1\% and 97.9\% of ECOWAS's Gross Domestic Product (GDP). We perform a Principal Component Analysis (PCA) on this data and retain the first factorial axis. This axis provides $97.5 \%$ of the information available. The proportion of the variance explained is $97.6 \%$ after taking Morocco into account. In addition, the correlation between the two indicators of monetary policy is very strong (0.98). We use the indicator obtained without Morocco in the rest of the analysis.

\subsection{Interest and Control Variables}

The first variable of interest is the monetary policy instrument. The other variables of interest are those on which we measure the effect of monetary policy (output). In addition, the model requires taking into account country characteristics (control variables). The first two control variables (liquidity and liabilities (liquid)) are proxies of the depth of the financial system while the third (Assets (liquid)) is a measure of the vulnerability of the banking sector. Bank concentration and market capitalization are used to characterize the financial structure of economies. Finally, debt and the quality of regulation are used to analyze the influence of the macroeconomic environment in the transmission of monetary policy.

The components of vector $\mathrm{Y}$ are respectively (and in order) the monetary policy instrument, the rate of inflation measured by the growth rate of the consumer price index, the primary difference of the effective exchange rate real, the cyclical component of the rate of credit to the economy and the cyclical component of the rate of growth of the economy. Therefore, we postulate that the monetary authorities control the money supply. Selecting variables allows us to explore the credit channel and indirectly the exchange rate channel. We also assess the macroeconomic effects of the monetary policy shock. Data on debit interest rates are only available from 2005. The use of these data can pose problems of precision of the estimators especially since the VAR models use the delays of the variables. In addition, analysis of the asset price channel requires finer intraday data to isolate the effect of monetary policy. In the following, we analyze the effects of a positive monetary policy shock (increase in the 
money supply) by one unit. The monetary policy shock is identified by orthogonalization (Cholesky decomposition). The data are at annual frequency over the period 1990-2015 and cover twelve ECOWAS countries to which we have added Morocco.

\section{Synoptic View of Monetary Policies in ECOWAS Countries}

A close look at the situation confirms that it is possible to group West African monetary problems into two broad categories:

a) the first brings together problems which can, to a certain extent, find effective solutions within the national efforts of each country, taken individually. These include insufficient capacity or strengthening the transmission channels for monetary policy.

b) The second category includes other more complex problems, such as the independence of monetary authorities, or difficulties with international ramifications, which require a supranational approach to be resolved effectively.

The inadequate functioning of the international monetary system, the destabilizing effects of international capital flows or even the monitoring of cross-border financial flows could fall into this second category. In the current context of globalization, where exchange rates between currencies are an extremely important factor in the competitiveness and economic performance of countries, the second category of problems identified above obviously plays a crucial role in determining the overall effectiveness of monetary policy. The resolution of monetary problems, and consequently the improvement of the effectiveness of monetary policy, is therefore also an inherently supranational issue.

The role of monetary policy in solving problems related to the international monetary environment has rarely been highlighted in the documentation and decisions of economic policy makers. Indeed, only the impact on the reduction of transaction costs, the facilitation of payments, and therefore of trade, are presented as expected benefits from monetary integration.

The resolution of monetary problems has been frequently undertaken at the supranational level by the international community. Careful observation, however, reveals a weakening of the multilateral frameworks for international monetary cooperation since the collapse of the Bretton Woods monetary system in 1971. This has led to a gradual fragmentation of international efforts to achieve international monetary cooperation. We have thus observed the emergence of various regional, bilateral frameworks, or bringing together countries which have certain affinities and decide to set up a framework for monetary cooperation. In addition to the fragmentation of multilateral monetary cooperation frameworks, there is a preponderance of bilateral frameworks in which dialogue aimed at resolving monetary disputes takes place mainly in a bilateral framework, the result being a function of the diplomatic and economic weight of the protagonists. The monetary debate between China and the United States and, to some extent, China and the euro area countries, is one example. Indeed, a revaluation of the yuan by the Chinese authorities has been and remains one of the key objectives of the international economic policy of the American government and of several European governments.

Current international monetary cooperation is characterized by mechanisms that create an environment in which national monetary practices differ from what they might be if the rules of good monetary neighborhood were observed. In such an environment, small countries find it difficult to maintain a value for their currency that is compatible with national growth and job creation objectives, unlike countries or groups of countries with greater economic and diplomatic weight..

If international monetary cooperation works so imperfectly, what should we think of monetary cooperation at the African level? Can West African countries count on the African Union's monetary cooperation program to find solutions to their monetary problems?

\section{Summury and Proposal of Monetary Policy Favorabl to Development}

All the above developments clearly underline the limits of the current mechanisms of international monetary cooperation. In a context where international political and diplomatic weight also weighs in the game of international monetary cooperation, regional monetary integration can offer West African countries an opportunity to strengthen their individual and collective position within the international cooperation. This vision, based not on the contribution to the resolution of internal monetary problems, but envisaged as an instrument to stem monetary shocks coming from the outside, has not been sufficiently recognized and analyzed, both in the theoretical literature and in considerations of policy makers. Better consideration of this dimension could help steer the debate on monetary integration in the right direction: that of rapid progress towards the single currency. It was in part to cope with the disintegration of the Bretton Woods international monetary system that Europe launched the process of European integration in order to collectively resist the new, more unstable and elusive world monetary environment.

Faced with fluctuations in the international monetary system, monetary integration can also play a stabilizing role upstream and downstream. Upstream, the supervisory structures and prudential systems put in place at the supranational level may prove to be stronger to reduce the risks of exposure. This is especially true for small countries like those in West Africa. Analysis of the impact of the 2008 financial crisis on the WAEMU countries revealed little impact on the financial sector. This is certainly due to the weak interconnection with international markets, but also to prudential rules and a risk management system for the Union 
banking sector, which have helped to reduce the exposure of WAEMU economies to financial assets at the origin of this financial crisis (BCEAO report on the impact of the financial crisis). Downstream, the principle of solidarity, essential for monetary integration, is set in motion in the event of shocks, particularly monetary, to mitigate the effects in the countries most affected, and preserve the common currency if necessary. In the European Union, the European Financial Stability Facility (EFSF) helped to resolve the sovereign debt crisis in 2009. In the WAEMU and the CEMAC zone, the principle of centralizing external reserves allows countries affected by a shock to their external payments to temporarily benefit from the resources of other countries.

The contribution of monetary integration to the resolution of monetary problems in West Africa also appears in the area of monetary management and banking supervision, which are confronted in West Africa, as in other regions in the world, to the development of banking groups and conglomerates and cross-border financial flows, the monitoring of which transcends national borders. The difficulties encountered lie in the difference in quality of supervision, reports and information available. It is therefore important that banking supervision has a regional character in order to ensure a holistic assessment of the situation in the financial sector and to strengthen the crisis management and resolution system. The debates following the sovereign debt crisis in the euro area have indeed highlighted the importance of ensuring regional coordination of financial sector supervision. This has led European countries to move towards the Banking Union.

Last but not least, monetary contribution is the development of financial systems and means of payment. The interconnection of the financial sectors in the sub-region offers the possibility of strengthening their efficiency through the widening of investment and liquidity investment opportunities on the one hand, and the sharing of best practices and financial infrastructures of on the other hand, which will make it possible to draw up the least developed financial systems

\section{Conclusion}

In conclusion, we underlined the essential role of regional monetary policy in the search for solutions to the development of West Africa. This role stems in particular from the preponderance of monetary problems of external origin from the region, from the limited contribution that international monetary cooperation can make to the resolution of these problems, and from the still insufficient progress of African monetary cooperation.

We have demonstrated in this article that, in its most complete form, the monetary integration of West Africa is the creation of a single currency. It remains timely and relevant, despite the uncertainties recently arising with the euro crisis and the failure to meet the 2015 deadline for the launch of the single currency in the WAMZ. The single currency would provide West African countries with an opportunity to more effectively resolve the many monetary problems they face today. Indeed, in a context where the West African countries are experiencing serious monetary problems of external origin which cannot be solved alone, and where the mechanisms of international monetary cooperation only work imperfectly, the single currency offers them an opportunity to pool their monetary means, an essential condition for the pursuit of their individual and collective monetary objectives in the current international context.

The option adopted by the West African countries of going directly to a monetary union in ECOWAS, by eliminating the intermediate stage envisaged for the countries of the WAMZ, seems the most adapted to the economic and political context of the region. In this regard, it seems that, to reduce the risks of a further postponement likely to affect the credibility of the process, the authorities should favor the Big-Bang option in 2020. In other words, all the member countries would participate to the single currency in 2020, and those who cannot meet the ex ante convergence criteria could do so ex post. Of course, government efforts will need to be sustained to meet the convergence criteria by 2020 .

For a fully satisfactory implementation of the road map of the ECOWAS single currency program, it seems essential to quickly complete the studies which should lead in particular to the choice of the monetary and exchange policy framework and the statutes of the future ECOWAS Central Bank in 2020. In this regard, greater involvement and responsibility will have to be given to the central banks of the region in the conduct of these discussions and the implementation of critical actions for the effective introduction of the single currency. Strengthening communication and information on the monetary integration process among populations, parliaments and the private sector is necessary to consolidate membership of the single currency. The technical and financial partners, including the AfDB, should accompany this process by encouraging the pursuit of economic reforms in the countries, the carrying out of technical studies relating to the institutional and legal framework of the monetary policy of the single currency, and the dialogue for greater ownership of the process by the people and governments of West Africa. It is also important to think deeply, taking into account the new contingencies linked to the international health crisis created by COVID-19.

\section{References}

[1] Friedman, 1953; The Methodology of Positive Economics. Essays in Positive Economics (1953) publ. University of Chicago Press.

[2] Meade, 1957, The Balance-of-Payments Problems of a European Free-Trade Area, The Economic Journal, Volume 67, Issue 267, 1 September 1957, Pages 379-396.

[3] Scitovsky, 1958, Economic Theory and Western European Integration, Revue économique Année 1959 10-3 pp. 472-474.

[4] Mundell, R. A. (1961) «A Theory of Optimum Currency Areas», American Economic Review reproduit in Blejer. 
[5] Rose, 2000, One money, one market: the effect of common currencies on trade. Economic Policy, Volume 15, Issue 30, 1 April 2000, Pages 08-45.

[6] Bean, C. R. (1992), 'Economic and Monetary Union in Europe', Journal of Economic Perspectives, Vol. 6, pp. 31-52.

[7] Tavlas, G. S. (1994), «The Theory of Monetary Integration», Open Economies Review, vol. 5 n², 99, pp. 211-230.

[8] McKinnon, R. I. (1963), «Optimum Currency Areas», American Economic Review, vol. 52 pp. 717-725.

[9] Mishkin, Frederic S., 1996. The Channels of Monetary Transmission: Lessons for Monetary Policy (February 1996). NBER Working Paper No. w5464. Available at SSRN: https://ssrn.com/abstract=265157.

[10] Arnaud Parienty, 2016. Comment fonctionne la politique monétaire. Dans Alternatives Économiques 2016/2 ( $N^{\circ} 354$ ), page 76 .

[11] Misra, Kanishka, and Paolo Surico. 2014. "Consumption, Income Changes, and Heterogeneity: Evidence from Two Fiscal Stimulus Programs." American Economic Journal: Macroeconomics, 6 (4): 84-106.
[12] Barigozzi, Matteo and Hallin, Mark, 2015. Generalized dynamic factor models and volatilities: recovering the market volatility shocks. The Econometrics Journal. ISSN 1368-4221.

[13] Ehrmann, M., L. Gambacorta, J. Martinez Pagés, P. Sevestre and A. Worms (2003). 'Financial systems and the role of banks in monetary policy', in Angeloni I., A. K. Kashyap and B. Mojon (eds.), Monetary Policy Transmission in the Euro Area, Cambridge University Press, Cambridge.

[14] Towbin, Pascal \& Weber, Sebastian, 2013. "Limits of floating exchange rates: The role of foreign currency debt and import structure," Journal of Development Economics, Elsevier, vol. 101 (C), pages 179-194.

[15] Georgios Georgiadis, 2014, Towards an explanation of crosscountry asymmetries in monetary transmission, Journal of Macroeconomics $39 \cdot$ January 2012 with 10 Reads.

[16] Christian Saborowski; Sebastian Weber, 2013, Assessing the Determinants of Interest Rate Transmission Through Conditional Impulse Response Functions, Working Paper No. 13/23, IMF, ISBN/ISSN: 9781475525717/1018-5941. 